\title{
PERLAKUAN AKUNTANSI UNTUK ASET BERSEJARAHSTUDI KASUS PADA CANDI SAMBISARI
}

\author{
Lila Retnani Utami \\ Universitas Respati Yogyakarta \\ lilaretnaniutami@gmail.com
}

\begin{abstract}
Abstrak
Aset bersejarah merupakan aset yang penting bagikebudayaanmasyarakat dan sejarah bangsa serta sebagai identitas negara. Penelitian ini merupakan penelitian mengenai perlakuan akuntansi yang diterapkan untuk aset bersejarah di Indonesia yang berfokus pada analisis terhadap perlakuan akuntansi pada pengelolaan Candi Sambisari. Penelitian ini bertujuan untuk memahami apakah dinas terkait memahami makna aset bersejarah . Memahami apakah dinas terkait memahami pengakuan asset bersejarah Candi Sambisari. Memahami apakah dinas terkait memahami penilaian asset bersejarah Candi Sambisari. Memahami apakah dinas terkait memahami Pengungkapan asset bersejarah Candi Sambisari. Memahami apakah perlakuan akuntansi untuk Candi Sambisari sesuai dengan standar akuntansi yang berlaku saat ini.Penelitian ini merupakan penelitian kualitatif dalam lingkup paradigma interpretatif studi fenomenologi pada hasil wawancara dengan informan penelitian. Data yang dianalisis adalah hasil wawancara dengan akademisi, dinas terkait dan pengelola Candi Sambisari. Data tersebut didapatkan melalui proses wawancara, dokumentasi, analisis dokomen, dan penelusuran data online.

Hasil penelitian Pemahaman para pengelola berkenaan dengan pengertian asset bersejarah Candi Sambisari, berdasarkan ketiga inforan dari pengelola candi Sambisari sejalan dengan definisi PSAP No 07 tahun 2010.Pengakuan aset bersejarah yang digunakan untuk mengakui Candi Sambisari adalah mempunyai masa manfaat yang tidak terbatas sebagai sumber pendapatan namun untuk nilainya tidak dapat dihargai dengan rupiah, selama ini hanya dinilai jumlahnya, Candi Sambisari jumlahnya adalah 1. Penilaian aset bersejarah yang digunakan bahwa selama ini Candi Sambisari tidak dinilai atau Rp 0 hanya disebutkan kuantitanya 1, melihat hal tersebut jangan diartikan bahwa Candi Sambisari tidak mempunyai nilai, pemberian $\mathrm{Rp} 0$ ini ditujukan dalam pelaporan keuangan saja yang fungsinya mencatat segala macam aset yang dimiliki oleh negara dalam catatan laporan keuangan. Pengungkapan aset bersejarah yang digunakan Candi Sambisari tidak masuk dalam neraca, namun tanggungjawab pelaporan aset bersejarah ada dalam CaLK, ini merupakan sebuah bentuk tanggung jawab pihak pengelola dalam hal ini BPCG untuk memberikan laporan aset yang mereka kelola. Hasil temuan peneliti dapat menyimpulkan bahwa perlakuan akuntansi atas aset bersejarah yang dilakukan pengelola Candi Sambisari dalam hal ini adalah BPCG sesuai dengan standar akuntansi bagi aset bersejarah yang berlaku saat ini yaitu PSAP No 07 tahun 2010.
\end{abstract}

Kata Kunci: Akuntansi, Aset Bersejarah, Penilaian, Penyajian, Pengungkapan, Laporan Keuangan, Catatan Laporan Keuangan 


\section{PENDAHULUAN}

Aset bersejarah merupakan kekayaan yang sangat penting bagi budaya masyarakat dan identitas suatu negara, seperti yang telah disampaikan president pertama RI yaitu JASMERA jangan melupakan sejarah. Menurut Accounting Standards Board (2006) aset bersejarah adalah sebuah aset dengan kualitas sejarah, seni, ilmiah, teknologi, geofisik atau lingkungan yang dipegang dan dipelihara untuk berkontribusi bagi ilmu pengetahuan dan kebudayaan serta memberi manfaat bagi entitas pemegangnya. Manfaatnya dari aset bersejarah selain sebagai ideologi negara juga bermanfaat untuk kepentingan ekonomi sebagai wisata yang akan mendatangkan ekonomi, namun untuk aset bersejarah ini ada permasalahan dimana untuk pelestariannya belum mendapat perhatian secara maksimal.

Aset bersejarah perlu dilakukan pengelolaan yang baik, pengelolaan ini merupakan tanggung jawab dari pemerintah dengan tujuan untuk memperkuat budaya Indonesia. Pengelolaan ini meliputi aspek penetapan status aset bersejarah ini siapa yang mempunyai tugas pokok dan fungsi pengelolaannya. Kemudian Pemanfaatan yang jelas aset bersejarah ini bagi kepentingan dan kesejahteraan negara. Pelesatarian aset bersejarah ini, dalam hal pelestarian ini berhubungan dengan masalah pendanaan dan pemeliharaan aset bersejarah.

Aset bersejarah terdiri dari beberapa jenis diantaranya adalah bangunan bersejarah, monumen, situs arkeologi, kawasan konservasi, dan karya seni.Aset bersejarah adalah aset dengan kualitas spesifik yang tidak dapat direplikasi, serta tidak memiliki umur yang terbatas Aversano dan Ferrone (2012).Aversano dan Christiaens (2012) berpendapat bahwa aset bersejarah berbeda dengan aset pada umumnya karena aset tersebut tidak dapat diproduksi ulang, digantikan dan juga tidak memungkinkan kondisinya untuk diperdagangkan.

DinIndonesia aset bersejarah masih terdapat beberapa permasalahan yang perlundilakukan perbaikan. Menurut Kodomogasuki (2015):

1. Inventarisasi aset yang masih buruk. Inventarisasi aset ini terdiri atas dua aspek, yaitu inventarisasi fisik dan juga yuridis/legal.Aspek fisik terdiri 
atas bentuk, luas, lokasi, volume/jumlah, jenis, alamat dan lain-lain.Sedangkan aspek yuridis adalah status penguasaan, masalah legal yang dimiliki, batas akhir penguasaan dan lain-lain. Proses kerja yang dilakukan adalah pendataan, kondifikasi/labeling, pengelompokan, dan pembukuan/administrasi sesuai dengan tujuan manajemen aset. Hal ini terlihat dari masih terdapatnya aset-aset yang secara fisik ada tetapi tidak tercatat di dalam daftar aset, atau bahkan ada aset yang dikuasai oleh pihak ketiga tetapi dokumen legalnya dikuasai oleh pemerintah atau sebaliknya ada aset yang dikuasai oleh pemerintah tetapi dokumen legalnya belum lengkap.Seringkali dokumendokumen legal atas aset tersebut sulit ditemukan bahkan tidak dapat ditemukan.

2. Pemanfaatan aset bersejarah yang dimiliki kurang memberikan hasil yang maksimal.

Pemerintah yang dengan begitu gampangnya memberi hak pengelolaan atas aset-aset negara kepada pengusaha swasta tanpa kompensasi yang maksimal untuk menambah keuangan negara menjadi salah satu penyebab tidak maksimalnya pedapatan untuk menambah keuangan Negara.Contohnya KSO pengelolaan Hotel Indonesia dengan Grup Djarum.

3. Permasalahan dalam akuntansi aset bersejarah tersebut, baik dari segi pengakuan, penilaian, dan pengungkapan mempunyai pendapat yang berbeda beda.PengakuanSejumlah dewan standar akuntansi nasional dan internasional (misalnya IPSASB, Australia AASB, Selandia Baru FRSB, UK ASB) menganggap bahwa memasukkan aset bersejarah dalam neraca akan meningkatkan kualitas informasi yang dilaporkan.Pallot dan Mautz mengklasifikasikan aset bersejarah tersebut sebagai "community assets" dan "facilities assets".Pallot berpendapat bahwa aset bersejarah harus diklasifikasikan sebagai "community assets" karena pemilik mereka memiliki kepemilikan tidak sempurna karena tidak memiliki hak-hak ekonomi pada umumnya (hak pakai hasil, 
pemindahtanganan,

pemusnahan).Carnegie dan

Wolnizer berpendapat bahwa aset bersejarah dapat tidak dapat digambarkan sebagai aset keuangan dan tidak memenuhi syarat untuk diakui sebagai aset: aset warisan bukan merupakan aset, baik dalam hal akuntansi konvensional atau dalam istilah komersial. Akan lebih sesuai untuk mengklasifikasikan aset bersejarah tersebut sebagai kewajiban ataupun hanya sebagai fasilitas dan menyajikannya secara terpisahPenilaianakan sangat sulit atau hampir mustahil untuk menemukan metode yang dapat diterima secara universal dari penilaian aset tersebut dan ada banyak masalah untuk menyelesaikan aplikasi akuntansi akrual untuk aset bersejarah tersebutpada sektor publik. Ketidakmungkinan menjual aset bersejarah di pasar terbuka dan tujuan sosial yang dikandung didalamnya, sangat sering mencegah akuntan dari mendapatkan penilaian yang relevan dan/atau menunjukkan nilai jasa potensial yang terdapat pada

aset
tersebut.Pengungkapandengan

adanya masalah pengakuan dan juga penilaian dari aset bersejarah, secara otomatis juga terdapat masalah pada pengungkapan aset tersebut.

Perlakuan akuntansi untuk aset bersejarah masih mempunyai pendapat yang berbeda-beda tergantung dengan sifat entitas yang menaunginya dan juga sifat dari aset tersebut.Menurut Barton (2000), aset bersejarah harus disajikan dalam anggaran terpisah sebagai "aset layanan", sedangkan menurut Pallot (1990, 1992) aset bersejarah harus disajikan dalam kategori yang terpisah dari aset sebagai "aset daerah". Perbedaan tersebut memicu timbulnya kesulitan dalam menentukan satu ukuran atau standar yang tepat guna diaplikasikan bagi entitas yang mengelola aset bersejarah maupun aset itu sendiri.

Penelitian tentang akuntansi untuk aset bersejarah masih sedikit dilakukan di Indonesia. Penelitian yang dilakukan oleh peneliti sebelumnya adalah sebuah proses mencari akuntansi yang tepat untuk aset bersejarah. Aset bersejarah ini memiliki nilai seni, budaya, ekonomi yang tinggi, maka darinitu diperlukan perlakuan aset 
bersejarah yang tepat agar menjamin ketersediaan informasi yang berguna untuk pengambilan keputusan yang relevan dengan kebutuhan pengguna (stakeholder) dalam hal organisasi pengelola aset bersejarah.Pengguna tidak hanya ditekankan pada investor saja, tetapi lebih kepada masyarakat sebagai pembayar pajak (tax payer).

Candi-candi yang ada di wilayah Daerah Istimewa Yogyakarta sangat banyak sekali Candi Sambisari merupakan candi yang berada didusun Sambisari, desa Purwomartani, Kecamatan Kalasan, Sleman, DIY. Jarak dari Kota Yogyakarta hanya sekitar 12 $\mathrm{km}$ arah timur, atau kira-kira $4 \mathrm{~km}$ sebelum Kompleks Candi Prambanan. Letak candi ini tersembunyi di bawah tanah, terdiri dari kompleks candi induk dan 3 candi pewara atau candi pendamping dengan dikelilingi pagar batu 2 lapis. Untuk memasuki area candi terdapat 4 pintu masuk.Candi Sambisari dibangun sekitar abad 9 masehi pada masa kejayaan kerajaan Mataram Hindhu, Kemudian bangunan ini menghilang tertimbun endapan lahar Merapi.

Saat ini Candi Sambisari sudah dilakukan pemugaran, perbaikan, pembangunan infrastruktur yang baik telah dilakukan untuk menarik pengunjung dalam dan manca negara. Terbukti setelah dilakukan perbaikan diikuti dengan pembangunan infrastruktur banyak pengunjung yang berwisata di Candi tersebut. Setiap harinya banyak pedagang yang berjualan di tempat tersebut layaknya seperti tempat wisata terkenal lainnya. Di sekitar Candi Sambisari terdapat kuliner yang sangat terkenal untuk wisatawan dalam dan mancanegara yaitu soto bathok, tempat kuliner ini merupakan magnet buat pengunjung untuk datang ke candi Sambisari. Dahulunya pengunjung hanya mengisi buku tamu, namun saat ini ada tiket masuk yang harus dibayarkan pengunjung. Berdasarkan hal tersebut pemilihan obyek penelitian di candi Sambisari mempunyai alasan, saat ini candi Sambisari sedang berkembang pesat, dibuktikan dengan jumlah pengunjung yang meningkat dari tahun ke tahun, dengan adanya candi tersebut taraf ekonomi warga sekitar semakin meningkat. Agar sejak awal candi ini dapat dilestarikan dengan baik maka penelitian ini perlu dilakukan. 
Jurnal MONEX Volume 8 Nomor. 1 Januari 2019

p-ISSN: 2089-6778

e-ISSN: 2549-5054

Penelitian ini merupakan penelitian replikasi yang pernah dilakukan oleh peneliti sebelumnya yaitu oleh Fauziah Galuh Anggraini, Anis Chariri (2014) denagn judul Perlakuan Akuntansi Untuk Aset Bersejarah (Studi Fenomenologi pada Pengelolaan Candi Borobudur), menggunakan metode pendekatan kualitatif dalam lingkup paradigma interpretative, hasil yang diperoleh adalah aset bersejarah termasuk dalam golongan aset bukan liabilitas, sampai saat ini belum ada dasar penilaian yang dianggap paling tepat untuk Candi Borobudur, Balai Konservasi Borobudur sudah memenuhi tanggung jawabnya untuk memasukkan Candi Borobudur dalam laporan keuangan sebagaimana yang diwajibkan oleh pemerintah bahwa segala jenis aset negara harus diungkapkan dalam laporan keuangan, Praktik akuntansi yang diterapkan untuk Candi Borobudur sudah sesuai dengan standar akuntansi yang berlaku, karena Candi Borobudur juga diungkapkan dalam CaLK saja dan tanpa nilai hanya berupa jumlah unitnya. Perbedaan penelitian ini dengan penelitian sebelumnya adalah penelitian ini menggunakan obyek penelitian di Candi Sambisari.

\section{A. Rumusan Masalah}

Berdasarkan uraian di atas, masalah yang akan diteliti dalam penelitian ini adalah:

1. Bagaimana dinas terkait memahami makna aset bersejarah?

2. Bagaimana dinas terkait memahami pengakuan asset bersejarah Candi Sambisari?

3. Bagaimana dinas terkait memahami penilaian asset bersejarah Candi Sambisari?

4. Bagaimana dinas terkait memahami pengungkapan asset bersejarah Candi Sambisari?

5. Apakah perlakuan akuntansi untuk Candi Sambisari sesuai dengan standar akuntansi yang berlaku saat ini?

\section{TINJAUAN PUSTAKA}

\section{Teori}

\section{Pengertian Aset Bersejarah}

Pengertian aset bersejarah

menurut beberapa ahli adalah

sebagai berikut:

Menurut Christiaens (2004) dalam Aversano dan Christiaens (2012) Aset bersejarah adalah aset yang harus dimasukkan dalam neraca meskipun tidak memenuhi definisi resmi.Menurut 
Pedoman Standar Akuntansi Perlakuan akuntansi untuk aset Pemerintahan (PSAP) Aset bersejarah bersejarah sesuai dengan standar merupakan aset tetap yang dimiliki atau dikuasai oleh pemerintah yang karena umur dan kondisinya aset tetap tersebut harus dilindungi oleh peraturan yang berlaku dari segala macam tindakan yang dapat merusak aset tetap tersebut. Menurut Carnegie dan Wolnizer (1995) dalam Aversano dan Christiaens (2012) aset besejarah bukanlah aset dan akan lebih tepat diklasifikasikan sebagai liabilitas, atau secara alternatif disebut sebagai fasilitas dan menyajikannya secara terpisah (Heritage assets are not assets and it would be more appropriate to classify them as liabilities, or alternatively to call them facilities and show them separately)

\section{Kerangka Berfikir}

Pengelolaan terhadap aset bersejarah penting untuk dilakukan bagi pemerintah dan juga bagi masyarakat, pengelolaan ini diawali dengan mengetahui definisi dari aset bersejarah, kemudian bagaimana metode penilaian yang paling tepat digunakan atas aset bersejarah tersebut. Selanjutntya bagaimana menyajikan dan mengungkapkan aset bersejarah dalam laporan keuangan, 


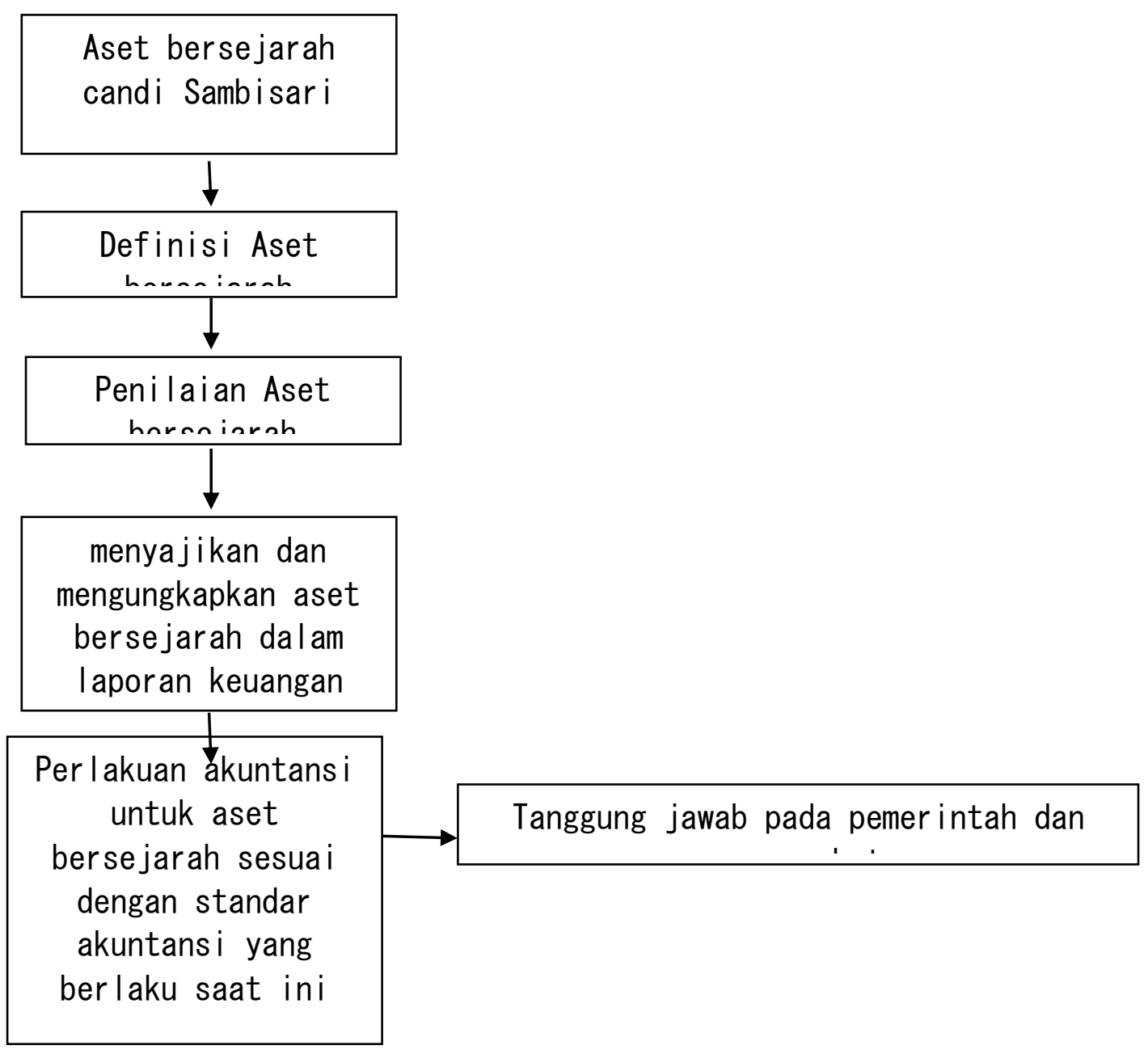

Gambar 2.1

\section{METODOLOGI PENELITIAN}

\section{Desain Penelitian}

Desain penelitian ini menggunakan pendekatan kualitatif dalam lingkup paradigma interpretatif. Penelitian kualitatif adalah penelitian yang bermaksud untuk memahami fenomena tentang apa yang dialami oleh subjek penelitian misalnya perilaku, persepsi, motivasi, tindakan, dll., secara holistik, dan dengan cara deskripsi dalam bentuk katakata dan bahasa, pada suatu konteks khusus yang alamiah dan dengan memanfaatkan berbagai metode alamiahMoleong (2007).

Selanjutnya diikuti dengan mengidentifikasi paradigma penelitian yaitu paradigma interpretatif yang 
memberikan pedoman terhadap pemilihan pendekatan yang tepat yaitu fenomenologi. Lalu, langkah terakhir adalah pemilihan metode pengumpulan dan analisis data yang tepat yaitu dengan wawancara, dokumentasi, analisis dokumen dan penelusuran data onlineFauziah Galuh Anggraini, Anis Chariri (2014)

Fenomenologi mencoba mengungkap struktur dan makna yang terpendam (implisit) dalam pengalaman manusia menjadi tampak jelas (eksplisit).Pendekatan fenomenologi adalah sebuah pendekatan yang menggunakan pengalaman hidup sebagai sebuah alat untukmemahami secara lebih baik tentang sosial budaya, politik atau konteks sejarah dimana pengalaman itu terjadiRoekhudin (2013).

\section{Metode Pengumpulan Data}

Metode pengumpulan data saja dalam penelitian kualitatif ini adalah metode wawancara, dokumentasi, analisis dokumen dan penelusuran data online. Kombinasi dari empat metode akan mendapatkan hasil lebih akurat dalam menjelaskan bagaimana perlakuan akuntansi untuk aset bersejarah pada Candi Sambisari.

\section{Alat Pengumpulan Data}

Alat Bantu Pengumpulan Data

1. Alat perekam

2. Membuat pedoman wawancara Pedoman wawancara digunakan untuk mengingatkan peneliti mengenai informasi-informasi apa yang akan digali. Pedoman wawancara juga kan memudahkan peneliti membuat kategorisasi dalam melakukan analisis data.

3. Kamera berguna untuk mendokumentasikan saat melakukan wawancara sehingga dapat dimafaatkan sebagai bukti penelitian.

4. Buku catatan digunakan untuk mencatat semua percakapan dengan informan.

\section{Metode Analisis Data}

Penelitian kualitatif tidak memiliki rumus atau aturan absolute untuk mengolahdan menganalisis data (Poerwandari, 2001). Teknik analisis data yang digunakan dalam penelitian ini adalah menggunakan langkah-langkah seperti yang dikemukakan oleh Burhan Bungin (2003:70), yaitu sebagai berikut:

1. Pengumpulan Data (Data Collection) Pengumpulan data merupakan bagian integral dari kegiatan analisis data. 
Kegiatan pengumpulan data pada penelitian ini adalah dengan menggunakan wawancara dan studi dokumentasi.

2. Reduksi Data (Data Reduction) Reduksi data, diartikan sebagai proses pemilihan, pemusatan perhatian pada penyederhanaan dan transformasi data kasar yang muncul dari catatancatatan tertulis di lapangan. Reduksi dilakukan sejak pengumpulan data dimulai dengan membuat ringkasan, mengkode, menelusur tema, membuat gugusgugus, menulis memo dan sebagainya dengan maksud menyisihkan data/informasi yang tidak relevan.

3. Display Data Display data adalah pendeskripsian sekumpulan informasi tersusun yang memberikan kemungkinan adanya penarikan kesimpulan dan pengambilan tindakan. Penyajian data kualitatif disajikan dalam bentuk teks naratif.Penyajiannya juga dapat berbentuk matrik, diagram, tabel dan bagan.

4. Verifikasi dan Penegasan Kesimpulan (Conclution Drawing and Verification) Merupakan kegiatan akhir dari analisis data. Penarikan kesimpulan berupa kegiatan interpretasi, yaitu menemukan makna data yang telah disajikan. Antara display data dan penarikan kesimpulan terdapat aktivitas analisis data yang ada. Dalam pengertian ini analisis data kualitatif merupakan upaya berlanjut, berulang dan terusmenerus.Masalah reduksi data, penyajian data dan penarikan kesimpulan/ verifikasi menjadi gambaran keberhasilan secara berurutan sebagai rangkaian kegiatan analisis yang terkait.Selanjutnya data yang telah dianalisis, dijelaskan dan dimaknai dalam bentuk kata-kata untuk mendiskripsikan fakta yang ada di lapangan, pemaknaan atau untuk menjawab pertanyaan penelitian yang kemudian diambil intisarinya saja.

Berdasarkan keterangan di atas, maka setiap tahap dalam proses tersebut dilakukan untuk mendapatkan keabsahan data dengan menelaah seluruh data yang ada dari berbagai sumber yang telah didapat dari lapangan dan dokumen pribadi, dokumen resmi, gambar, foto dan sebagainya melalui metode wawancara yang didukung dengan studi dokumentasi. 
HASIL PEMBAHASAN

Pemahaman Para Pengelola Berkenaan Dengan Pengertian

HeritageAsets

Pemahaman para pelaku pengelola candi Sambisari tentang makna aset bersejarah merupakan hal yang penting untuk melakukan analisa awal bagaimana perlakuan akuntansi candi Sambisari sebagai aset bersejarah (heritage assets). Peneliti beranggapan jika pengertian para pengelola candi Sambisari mengenai apa itu aset bersejarah akan dapat mempengaruhi aspek pengakuan, penilaian, penyajian dan pengungkapannya.

Peneliti bertanya kepada informan mengenai definisi aset bersejarah.Informan ini adalah ibu kepala bagian aset di BPCB, berikut kutipanpernyataan, mengenai pengertian aset saya adalah kekayaan yang berupa candi, museum, benda-benda yang merupakanpeninggalan masa lampau yang berkaitan dengan unsur-unsur sejarah.Kepemilikan aset tersebut bukan karena pembelian namun karena memang sudahada dan tersedia di negara ini" Sedangka tidak bisa ternilai harganya yang dimiliki oleh wilayah Sleman ditemukankemudian dipugar dibuka dan mendatangkan pendapatan dari pengunjung, selain mendatangkan pendapatan dari pengunjung juga berkewajiban untuk melakukan pemeliharaan aset tesebut agar terjaga kelestariannya.Hasil transkrip percakapan dengan menunjukkan bahwa informan melihat aset bersejarah sebagai bagian dari aset yang dimiliki dan dikuasai oleh negara.Aset bersejarah merupakan aset yang mengandung unsur barang yang bersejarah ruang, waktu dan manusia, sehingga patut untuk dipelihara dan dijaga kelestariannya.Keberadaan aset bersejarah dilindungi oleh negara melalui daerahdimana aset tersebut berada dan diletakkan dan perlu perlindungan agar tidak diakui pihakpihak tertentu.

Pada waktu yang hampir bersamaan, peneliti juga mengajukan pertanyaan yang sama kepada informan lain yaitu Ka Sub Pengolahan Data. Informan mengungkapkan hal yang hampir sama dengan yang disampaikan sebelumnya. Wawancara adalah sebagai berikut:Aset bersejarah menurutbenda,gedungsayayangmempunyaiadala $\mathrm{h}$ be umur ekonomis yang panjang yang dapat mendatangkan pendapatan apabiladijadikan sebagai sumber 
pendapatan, namun juga perlu banyak biaya untuk mempertahankan keberadaanya. Aset bersejarah harus mempunyai nilai-nilai budaya yang terkadung didalam aset tersebut.Candi sambisari ini sejakditemukankemudian dipugar dan dibuka.Menurut penuturannya, aset bersejarah ini berhubungan dengan salah satu kriteria dari aktiva tetap yaitu punya manfaat yang panjang, yaitu mempunyai masa manfaat lebih dari 1 tahun. Kemudian pada hari berbeda, peneliti melakukan wawancara dengan informan lain yang berbeda yaitu bagian keuangan. Peneliti mengajukan pertanyaan yang sama perihal definisi assetbersejarah kepada informan. Beliau menu karena pengadaannya atau keberadaanya tidak lepas dari nilai sejarah yangmelekat pada aset tersebut. .makanya beberapa hal yang mencirikan aset tersebut dianggap sebagai aset bersejarah pertama karena ada nilai kultural, lingkungan, pendidikan dan sejarah tidak mungkin secara penuh dilambangkan dengan nilai keuangan...kemudian yang kedua peraturan dan hukum yang berlaku melarang atau membatasi secara ketat pelepasan untuk dijual...yang ketiga tidak mudahuntuk diganti dan nilainya akan terus meningkat selama waktu berjalan walaupun kondisi fisiknya semakin menurunkeempat, sulit untuk mengestimasikan masa manfaat.

Pada kesempatan lain peneliti berkunjung kembali ke BPCBuntuk menemui bagian keuangan sebagai kepala keuangan di bidang aktiva, beliau kami wawancara juga berkenaan dengan aset bersejarah. Beliau juga berpendapat tidak beda dengan yang disampaikan dua informan sebelumnya, sebagai berikut hasil petikan wawancaranya:Aset bersejarah adalah kelompok aset dikatakan sebagai aset karena punyai nilai manfaat untuk masa depan. Aset bersejarah dapat bermanfaat untuk masa depan antara lain melalui jumlah pengunjung dari dalam dan turis yang dapat datang setiap waktunya, manfaat masa depan lain adalah tidak hanya didapatkan oleh entitas yang memilikinya namun juga keuntungan bagi masyarakat, Bagi saya dari riilnya Candi Sambisari merupakan aset pemerintah, walaupun dari lain pihak merupakan kewajiban kita, ketika aset dimiliki oleh suatu entitas, maka entitas mempunyai kewajiban untukmengelolanya.

Keterangan dari ketiga informan 
disimpulkan bahwa aset bersejarah Candi Sambisari adalah aset yang mempunyai nilai sejarah yang tinggi, mengandung lingkungan dan pengetahuan yang berhubungan dengan peristiwa masa lampau yang dianggap bernilai, oleh pemerintah perlu untuk dilindungi dan terus dilestarikan dalam waktu yang tidak terbatas, agar generasi berikutnya dapat terus menikmati peninggalan sejarah nenek moyangnya. Keberadaan aset bersejarahbelum dapat dinilai harga atau nominalmya dan jika nilainya dapat diperkiranmaka nilainya akan bertambah terus, sehingga sulit untuk mengestimasi nilai ekonomisnya. Meskipun candi jika tidak dipelihara secara fisik akan menurun seiring berjalannya waktu, namun cenderung mempunyai masa manfaat yang tidak terbatas. Definisi aset bersejarah yang telah disampaikan oleh 3 informan di atas sejalan dengan PSAP No.07 tahun 2010 yang menyatakan bahwa beberapa aset tetap dijelaskan sebagai aset bersejarah dikarenakan kepentingan budaya dan sejarah. Meskipun PSAP No.07 tidak menyebutkan definisi sesungguhnya dari heritage assets, akan tetapi PSAP No.07 menjabarkan karakteristik-karakteristik suatu heritage assets seperti yang sudah dijelaskan di atas.

Dalam aset bersejarah mengandung kriteria umur, semakin aset tersebut umurnya semakin lama maka nilainya akan semakin tinggi. Seperti pada UU No 11 tahun 2010 tentang cagar budaya, aset dikatakan sebagai aset bersejarah adalah yang memenuhi beberapa persyaratan sebagai berikut

1. Berusia 50 tahun atau lebih

2. Mewakili masa gaya paling singkat berusia 50 tahun Kriteria di atas menunjukkan bahwa aset bersejarah (heritage assets) merupakan bagian yang tidak dapat dilepaskan dari Cagar Budaya.

Menurut UU No. 11 Tahun 2010, cagar budaya adalah warisan budaya bersifat kebendaan berupa Benda Cagar Budaya, Bangunan Cagar Budaya, Struktur Cagar Budaya, Situs Cagar Budaya, dan Kawasan Cagar Budaya di darat dan/ atau di air yang perlu dilestarikan keberadaannya karena memiliki nilai penting bagi sejarah, ilmu pengetahuan, pendidikan, agama, dan/ atau kebudayaan.

\section{Pengakuan Aset Bersejarah Yang Digunakan.}




Berdasarkan hasil wawancara
dengan bagian keuangan di

BPCBtentang bagaimana pengakuan aset bersejarah Candi Sambisari.Pengakuan aset bersejarah Candi Sambisari sebagai barang berwujud, manfaatnya tidak terbatas semakin tua semakinberharga, namun memang nilai candi ini tidak dapat diukur.Untuk memperolehcandi ini dibutuhkan biaya-biaya seperti pembebasan tanah, kemudian biayabiaya perolehansebesar biaya pemugaran, pemeliharaan.Namun nilai yang disajikan tidak ada adanilainya diakui hanya kuantiti 1 saja.Candi tidak dinilai rupiahkan dikarenakan tidak dimaksudkan untuk dijual belikan. Candi dimaksudkan akan dilestarikan oleh pemerintah sepanjang masa. Candi punya masa manfaat tak terbatas, manfaat yang didapatkan dari segi ekonomi adalah mendapatkan pendapatan atau pemasukan dari kunjungan wisata. Pada inti dari pengakuan aset bersejarah candi Sambisari adalah manfaat ekonomi masa depan dapat diperoleh sebagai sumber pendapatan pemerintah dan namun nilainya tidak dapat diukurhanya dinilai 1 dalam laporan

\section{PenilaianAset}

\section{Bersejarah Yang}

\section{Digunakan}

Suatu penilaian aset tetap selalu berkaitan dengan pengakuan. Pada dasarnya, ada standar yang mengatur tentang syarat bahwa suatu benda akan diakui sebagai aset. Aset tetap ini salah satunya aset bersejarah yang mempunyai ciri yang unik, ciri inilah yang akan membedakan antara aset bersejarah dan aset lainnya. Penialian ini secara garis besar berkaitan dengan penentuan sejumlah rupiah yang diajukan atas aset tersebut yang fungsinya akan disajikan dalam laporan keuangan. Memang banyak metode dalam melakukan penilaian aset, namun untuk aset bersejarah ini dapat dinilai.Kenapa tidak dapat dinilai karena ada banyak alasan yang melatar belakanginya. Berikut ini hasil wawancari dari informan kami di BPCB sebagai berikut:Jadi untuk masalah

penilaianriinitidakmudahberapabagi har saya untuk menetapkan nilai berapa, takut salah nilainya, tapi saya yakin nilaicandi ini tidak terhingga karena masa manfaatnya tidak terbatas. Selain itu candi memang sampai saat ini tidak dapat dinilai karena tidak akan diperjual belikan juga. Bagi saya sebagai 
pengelola candi merasa tabu kalau harus menilai berapa harga candi ini, jika saya menyebutnya nilai moneter tidak akan dapat mewakili nilainya

PengungkapanAset Bersejarah Yang

\section{Digunakan}

Pengungkapan dalam laporan

keuangan atas aset bersejarah memang sangat penting dimaksudkan untuk menyajikan informasi keuangan untuk pihak-pihak yang berkepentingan dan membutuhkan. BPCB memberikan keterangan kepada peneliti tentang penyajian aset bersejarah candi Sambisari bahwa candi Sambisari dilaporkan dalam laporan sebagai berikut:

\section{Tabel 1}

\section{Contoh Catatan Atas Laporan Keuangan (Laporan Barang Bersejarah)}

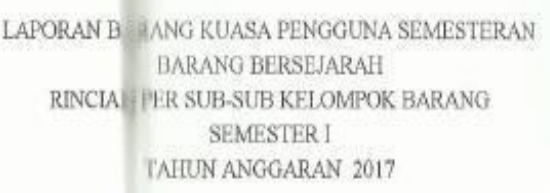

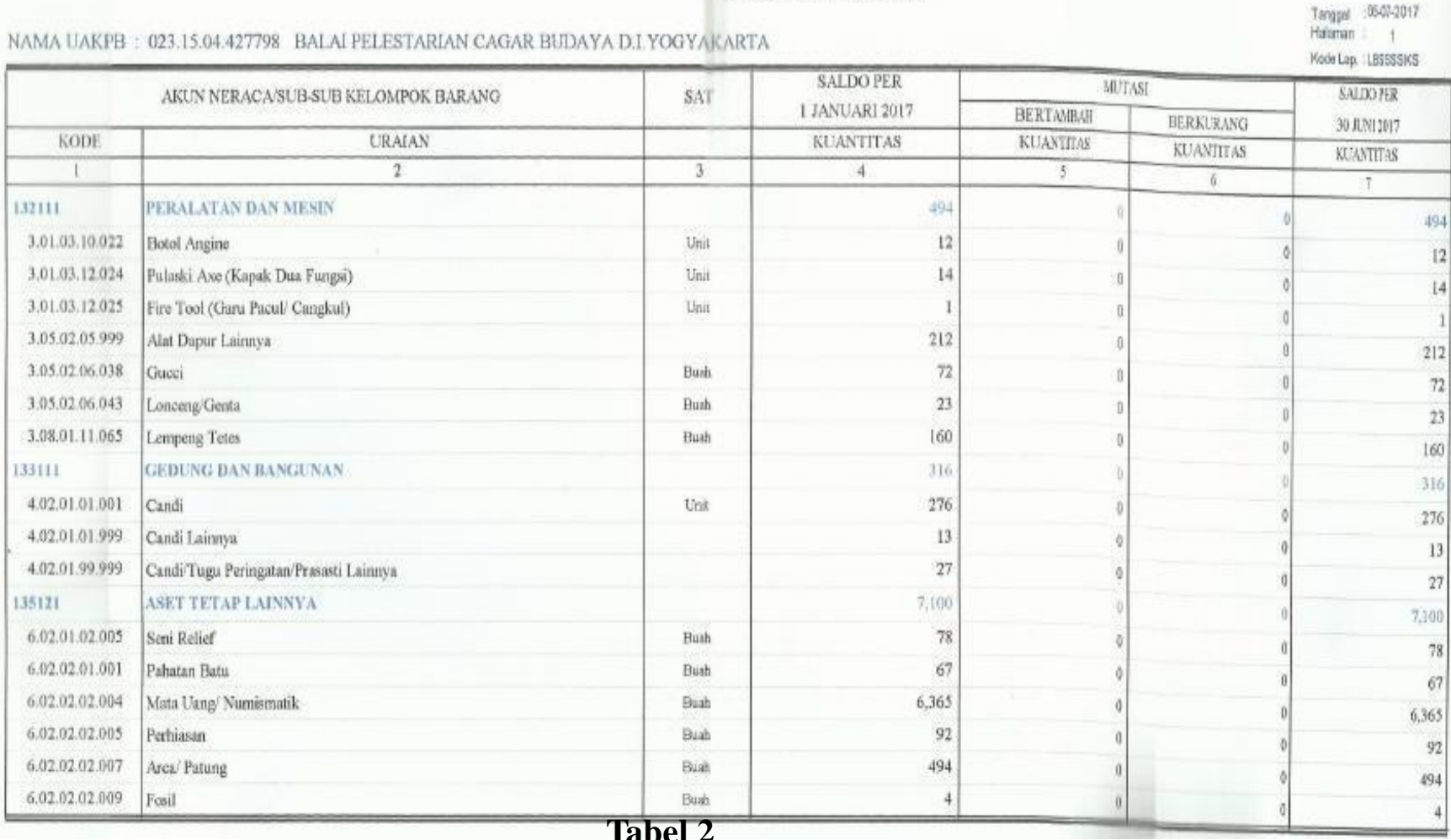

Tabel 2

Contoh Catatan Atas Laporan Keuangan (Laporan Barang Bersejarah) 
Jurnal MONEX Volume 8 Nomor. 1 Januari 2019

p-ISSN: 2089-6778

e-ISSN: 2549-5054

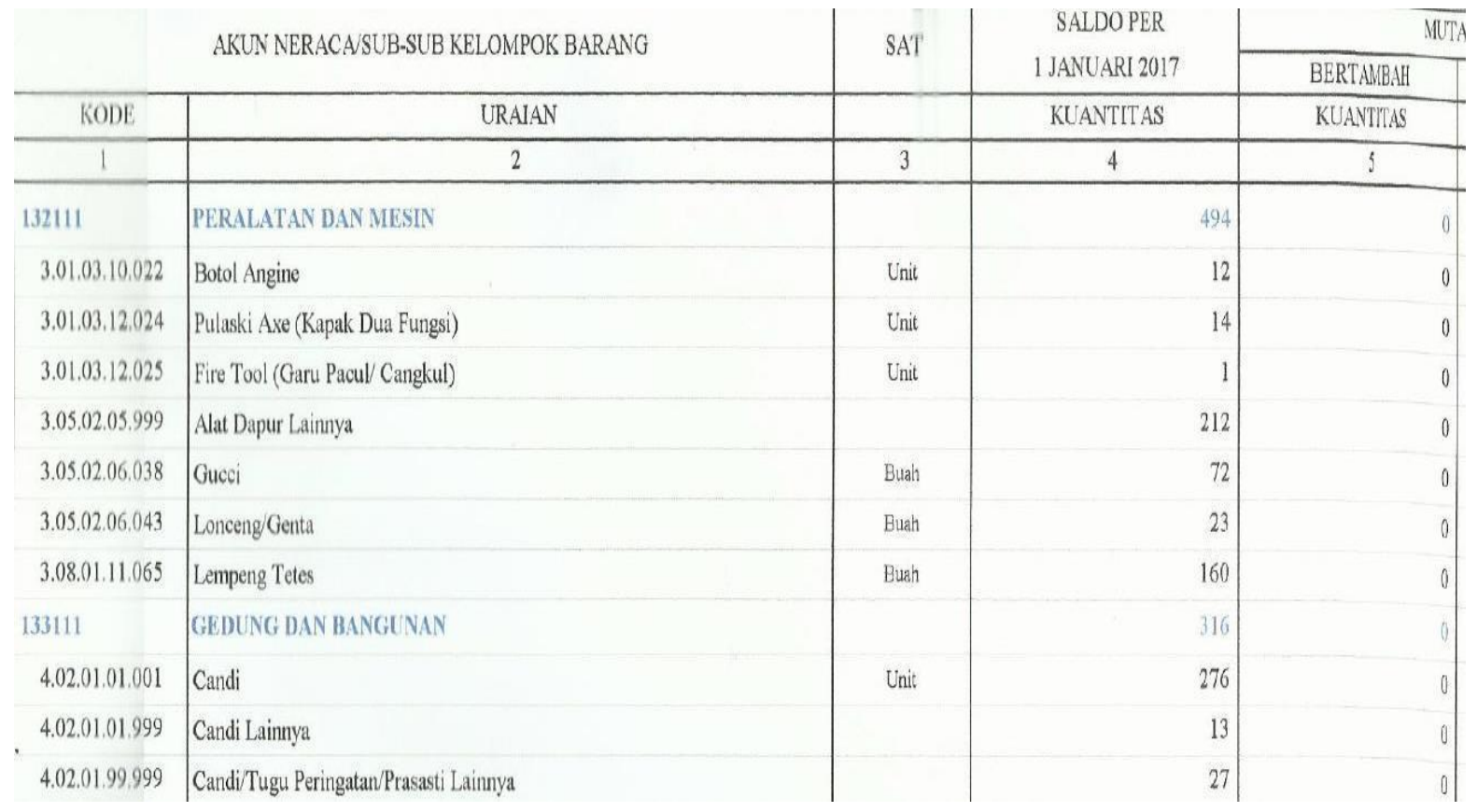


Aset bersejarah yang tersebar di wilayah Yogyakarta dansekitarnya yang berupa bangunan candi sangat banyak sekali, di dalam laporan barang bersejarah tercatat 316 candi salah satunya adalah candi Sambisari.Pengelolaan candi Sambisari ditangani oleh BPCG dibawah kementrian pendidikan dan kebudayaan, dengan demikian pihak team $\mathrm{BPCH}$ tidak mampu menjawab kenapa penyajian aset bersejarah candi Sambisari adalah tidak bernilai atau 0 .

Dalam tabel diatas menunjukkan dan membutikan bahwa akun candi salah satunya candi Sambisari telah diungkapkan dalam laporan keuangan masuk dalam Catatan Atas Laporan Keuangan (CaLK).Dalam laporan keuangan yaitu neraca candi tidak masuk dalam akun aktiva tetap dikarenakan tidak mempunyai nilai atau Rp0, tidak mempunyai nilai ini dipandang bahwa candi mempunyai masa manfaat ta terbatas.Apabila candi masuk dalam neraca, hal ini menyebabkan adanya kewajiban untuk menilai candi tersebut dan menyebabkan candi masuk dalam aktiva tetap di neraca.Walaupun candi Sambisari tidak masuk dalam neraca, namun tanggungjawab pelaporan aset bersejarah ada dalam CaLK, ini merupakan sebuah bentuk tanggung jawab pihak pengelola dalam hal ini BPCG untuk memberikan laporan aset yang mereka kelola.

\section{Kesesuaian Standar Akuntansi}

Pemerintahan Dengan

\section{StandarAkuntansi Yang Diterapkan}

Pada Pengelolaan Candi Sambisari

Akuntansi khusus untuk aset bersejarah telah diatur dalam PSAP 07 tahun 2010 yang isinya adalah sebagai berikut:

PSAP 07 tidak mengharuskan pemerintah untuk menyajikan aset bersejarah (heritage assets) di neraca namun aset tersebut harus diungkapkan dalam Catatan atas Laporan Keuangan.Beberapa aset tetap dijelaskan sebagai aset bersejarah dikarenakan kepentingan budaya, lingkungan, dan sejarah.Contoh dari aset bersejarah adalah bangunan bersejarah, monumen, tempat-tempat purbakala (archaeological sites) seperti candi, dan karya seni (works of art).

Aset bersejarah biasanya diharapkan untuk dipertahankan dalam waktu yang tak terbatas.Aset bersejarah biasanya dibuktikan dengan peraturan 
perundang-undangan. Pemerintah mungkin mempunyai banyak aset bersejarah yang diperoleh selama bertahun-tahun dan dengan cara perolehan beragam termasuk pembelian, donasi, warisan, rampasan, ataupun sitaan. Aset ini jarang dikuasai dikarenakan alasan kemampuannya untuk menghasilkan aliran kas masuk, dan akan mempunyai masalah sosial dan hukum bila memanfaatkannya untuk tujuan tersebut.

Aset bersejarah harus disajikan dalam bentuk unit, misalnya jumlah unit koleksi yang dimiliki atau jumlah unit monumen, dalam Catatan atas Laporan Keuangan dengan tanpa nilai. Biaya untuk perolehan, konstruksi, peningkatan, rekonstruksi harus dibebankan dalam laporan operasional sebagai beban tahun

terjadinya pengeluaran tersebut. Beban tersebut termasuk seluruh beban yang berlangsung untuk menjadikan aset bersejarah tersebut dalam kondisi dan lokasi yang ada pada periode berjalan.

Beberapa aset bersejarah juga memberikan potensi manfaat lainnya kepada pemerintah selain nilai sejarahnya, sebagai contoh bangunan bersejarah digunakan untuk ruang perkantoran. Untuk kasus tersebut, aset ini akan diterapkan prinsip-prinsip yang sama seperti aset tetap lainnya. Untuk aset bersejarah lainnya, potensi manfaatnya terbatas pada karakteristik sejarahnya, sebagai contoh monumen dan reruntuhan (ruins).

Untuk pengelolaan candi Sambisari dilakukan oleh BPCG dari penemuan candi yang dilaporkan oleh warga, kemudian upaya pembebasan tanah kawasan candi beserta pembelian tanahnya.Pemugaran candi serta pemeliharaan candi telah dilakukan oleh BPCG.Selanjutnya keberadaan aset bersejarah itu dilaporkan dalam CaLK dengan akun bernama candi dalam satuan unit, candi tidak mempunyai nilai atau Rp 0. Keberadaan candi itu mempunyai manfaat di masa mendatang untuk menghasilkan pendapatan yang akan memakmurkan masyarakat. Dengan demikian hasil temuan peneliti dapat menyimpulkan bahwa perlakuan akuntansi atas aset bersejarah yang dilakukan pengelola candi Sambisari dalam hal ini adalah BPCG sesuai dengan standar akuntansi bagi aset bersejarah yang berlaku saat ini yaitu PSAP No 07 tahun 2010 


\section{SIMPULAN}

1. Pemahaman para pengelola berkenaan dengan pengertian asset bersejarah Candi Sambisari, berdasarkan ketiga inforan dari pengelola candi Sambisari sejalan dengan definisi PSAP No 07 tahun 2010.

2. Pengakuan aset bersejarah yang digunakan untuk mengakui Candi Sambisari adalah mempunyai masa manfaat yang tidak terbatas sebagai sumber pendapatan namun untuk nilainya tidak dapat dihargai dengan rupiah, selama ini hanya dinilai jumlahnya, Candi Sambisari jumlahnya adalah 1.

3. Penilaian aset bersejarah yang digunakan bahwa selama ini Candi Sambisari tidak dinilai atau Rp 0 hanya disebutkan kuantitanya 1, melihat hal tersebut jangan diartikan bahwa Candi Sambisari tidak mempunyai nilai, pemberian $\mathrm{Rp}$ 0 ini ditujukan dalam pelaporan keuangan saja yang fungsinya mencatat segala macam aset yang dimiliki oleh negara dalam catatan laporan keuangan.
4. Pengungkapan aset bersejarah yang digunakan Candi Sambisari tidak masuk dalam neraca, namun tanggungjawab pelaporan aset bersejarah ada dalam CaLK, ini merupakan sebuah bentuk tanggung jawab pihak pengelola dalam hal ini BPCG untuk memberikan laporan aset yangmereka kelola.

5. Hasil temuan peneliti dapat menyimpulkan bahwa perlakuan akuntansi atas aset bersejarah yang dilakukan pengelola Candi Sambisari dalam hal ini adalah BPCG sesuai dengan standar akuntansi bagi aset bersejarah yang berlaku saat ini yaitu PSAP No 07 tahun 2010

\section{SARAN}

Saran dari peneliti adalah jika kita akan melakukan penilaian dan pengungkapan aset bersejerah candi Sambisari perlu untuk melihat standar akuntansi pemerintahan untuk asset bersejarah di Amerika bahwa asset bersejarah dinilai berdasarkan harga perolehan. Jadi untuk mengakui asset bersejarah dapat dilakukan jika pemerintah mengetahui secara pasti dengan adanya bukti yang 
ditemukan diawal proses pengakuan berapa harga perolehan yang terdapat pada asset bersejarah disana

\section{DAFTAR PUSTAKA}

Act Accounting Policy. 2009. Heritage and Community Assets:Measurement of Heritage and Community Assets

Accounting Standards Board (2006)

Agustini, Aisa Tri. 2011, “Arah Pengakuan, Pengukuran, Penilaian, dan Penyajian Aset Bersejarah dalam Laporan Keuangan pada Entitas Pemerintah Indonesia (Studi Literatur), Skripsi, Fakultas Ekonomi, Jurusan Akuntansi, Universitas Jember, Jember

Aversano, Natalia dan Johan Christiaens. 2012. Governmental Financial Reporting of Heritage Assets in The Perspective of User Needs. Social Science Research Network. http://papers.ssrn.com. Diakses tanggal 29 Mei 2013.
Aversano, Natalia dan Caterina Ferrone. 2012. The Accounting Problem of Heritage Assets. Advanced Research in Scientific Areas

Bungin, Burhan. 2003. Analisis Data Penelitian Kualitatif . Jakarta: PT Raja Grafindo Persada.

Fauziah Galuh Anggraini, Anis Chariri (2014) Perlakuan Akuntansi Untuk Aset Bersejarah (Studi Fenomenologi pada Pengelolaan Candi Borobudur) DIPONEGORO JOURNAL OF ACCOUNTING Volume 2, Nomor 2, Tahun 2014

Moleong, Lexy J. (2007) Metodologi Penelitian Kualitatif, Penerbit PT Remaja Rosdakarya Offset, Bandung

Poerwandari, Kristi. (2001). Pendekatan kualitatif untuk penelitian perilaku manusia. Fakultas Psikologi, Universitas Indonesia : Lembaga Pengembangan Sarana Pengukuran dan Pendidikan Psikologi (LPSP3). 
Jurnal MONEX Volume 8 Nomor. 1 Januari 2019

p-ISSN: 2089-6778

e-ISSN: 2549-5054

Pedoman Standar Akuntansi Pemerintah. 2011. Nomor 07: Aset Tetap

PSAP Nomor 07 Tahun 2010

Retha Maya Masitta, Anis Chariri (2015) Problematika Akuntansi Hertage Assets: Pengakuan, Penilaian, Pengungkapan, dalam laporan keuangan (Studi Kasus pada Pengelolaan Museum Jawa Tengah Ronggowarsito) DIPONEGORO JOURNAL OF ACCOUNTING Volume 4, Nomor 3, Tahun 2015,

Sugiyono. 2010. Metode Penelitian Kuantitatif, Kualitatif dan R\&D. Bandung: Alfabeta.

http://kodomogasuki.blogspot.co.id/2015

106/aset-pemerintah-yang-bersifat

khusus.html

http://www.njogja.co.id/wpcontent/uploa ds/2014/12/lokasi_candi_sambisari_yog yakarta.jpg 